\title{
ANALISIS PENGARUH RETURN ON EQUITY, FIRM SIZE, CURRENT \\ RATIO DAN INSTITUTIONAL OWNERSHIP TERHADAP DIVIDEND PAYOUT RATIO DENGAN DEBT TO EQUITY RATIO SEBAGAI VARIABEL INTERVENING
}

\author{
Ika Rosyada Fitriati ikarosyada@edu.unisbank.ac.id \\ Program Studi Manajemen, Fakultas Ekonomika dan Bisnis \\ Universitas Stikubank (UNISBANK) Semarang \\ Mohammad Chabachib chabachib@undip.ac.id \\ Harjum Muharam hardjum@gmail.com \\ Fakultas Ekonomika dan Bisnis, Universitas Diponegoro (UNDIP) Semarang
}

\begin{tabular}{l}
\hline Info Artikel \\
\hline Sejarah Artikel \\
Diterima \\
Disetujui \\
Dipublikasikan \\
Keywords : \\
return on equity, firm size, \\
current ratio, institutional \\
ownership, debt to equity \\
ratio dan dividend payout \\
ratio
\end{tabular}

Abstrak

Penelitian ini bertujuan untuk menguji pengaruh variabel return on equity, firm size, current ratio dan institutional ownership terhadap dividend payout ratio dengan debt to equity ratio sebagai variabel intervening. Pengambilan sampel menggunakan purposive sampling. Data diambil dari Indonesian Capital Market Directory (ICMD). Uji kelayakan model menggunakan uji multikolinieritas, uji koefisien determinasi dan uji signifikansi. Teknk analisis menggunakan analisis jalur dan sobel test. Hasil penelitian ini menunjukkan bahwa current ratio dan institutional ownership berpengaruh negatif signifikan terhadap debt to equity ratio, firm size dan current ratio berpengaruh positif signifikan terhadap dividend payout ratio, debt to equity ratio berpengaruh negatif signifikan terhadap dividend payout ratio serta debto equity ratio mampu memediasi pengaruh current ratio terhadap dividend payout ratio dan pengaruh institutional ownership terhadap dividend payout ratio.

\begin{tabular}{l} 
ANALYSIS OF EFFECT OF RETURN ON EQUITY, FIRM SIZE, CURRENT \\
RATIO AND INSTITUTIONAL OWNERSHIP TOWARD DIVIDEND PAYOUT \\
RATIO WITH DEBT TO EQUITY RATIO AS AN INTERVENING VARIABLE \\
\hline
\end{tabular}

Abstract

The aimed of this study is examine the effect of variable return on
equity, firm size, current ratio and institutional ownership toward
dividend payout ratio with debt to equity ratio as an intervening
variable. Sampling using purposive sampling. Data taken from
Indonesian Capital Market Directory (ICMD). The test of
feasibility models using multicoliniarity test, coefficient
determination test and test of significance. The analysis
technique using path analysis and sobel test. The result of this
study indicate that the current ratio and institutional ownership
have significant negative effect on debt to equity ratio, firm size
and current ratio have significant positive effect on dividend
payout ratio, debt to equity ratio has significant negative effect
on dividend payout ratio and the debt to equity ratio capable of
mediating influence current ratio toward dividend payout ratio
and the effect of institutional ownership toward dividend payout
ratio. 


\section{PENDAHULUAN}

Pasar modal merupakan instrumen investasi yang sedang beekembang pesat karena faktor kemudahan transaksi, keterbukaan informasi dan besarnya keuntungan yang ditawarkan. Keuntungan dalam investasi pada pasar modal dapat berupa dividen dan capital gain. Kebijakan dividen perusahaan dapat dilihat dari besarnya dividend payout ratio. Dividen payout ratio menentukan porsi keuntungan yang akan dibagi kepada pemegang saham dan yang akan ditahan untuk digunakan sebagai modal operasi perusahaan pada periode selanjutnya. Kebijakan dividen diambil dengan memertimbangkan faktor internal maupun eksternal perusahaan. Faktor internal perusahaan antara lain berupa profitabilitas, firm size, likuiditas, kepemilikan institusi dan kebijakan hutang.

Profitabilitas dapat diukur melalui return on equity (ROE), yaitu dengan membandingkan laba bersih perusahaan terhadap ekuitasnya. Return on equity merupakan salah satu indikator yang seringkali digunakan investor untuk menilai perusahan sebelum melakukan investasi. Ghi dan Ba (2015) menyatakan bahwa return on equity berpengaruh positif signifikan terhadap dividend payout ratio. Peningkatan profit suatu perusahaan akan meningkatkan kemampuan perusahaan untuk membayarkan dividen. Hasil penelitian tersebut sejalan dengan hasil penelitian hasil penelitian Nerviana (2015), Hejazi dan Moshtagin (2014) serta mendukung signaling theory yang menyatakan bahwa profitabilitas memiliki pengaruh positif terhadap pembayaran dividen tunai (Tariq, 2015). Namun, hasil berbeda ditemukan pada penelitian Komala dan Nuroho (2013) yang menyatakan bahwa return on equity berpengaruh negatif signifikan terhadap dividend payout ratio.

Firm size merupakan ukuran perusahaan. Penelitian terdahulu telah banyak dilakukan untuk mengetahui pengaruh firm size terhadap dividend payout ratio. Al Najjar (2016) menemukan bahwa firm size berpengaruh positif signifikan terhadap dividend payout ratio. Firm size yang besar memungkinkan perusahaan untuk membayar dividen lebih besar. Hasil penelitian tersebut konsisten dengan penelitian sebelumnya yang dilakukan oleh Mehta (2012) serta Hejazi dan Moshtaghin (2014). Namun, hasil berbeda ditemukan oleh Shubiri (2011) yang menyatakan firm size berpengaruh negatif signifikan terhadap dividend payout ratio, sedangkan Nerviana (2015) menemukan bahwa ukuran perusahaan tidak memiliki pengaruh terhadap dividend payout ratio.

Current ratio merupakan salah satu rasio likuiditas yang mengukur seberapa jauh aktiva lancar perusahaan dapat dipakai untuk memenuhi kewajiban lancarnya. Current ratio akan perlu dikelola dengan optimal agar dapat menghasilkan keuntungan yang maksimal. Mehta (2012) menyatakan bahwa likuiditas merupakan faktor penentu kebijakan dividen. Perusahaan yang memiliki likuiditas tinggi akan memiliki kemampuan untuk membayar dividen tunai (cash dividend). Hal ini sejalan dengan penelitian Wasike (2015) dan Ahmed (2015) yang menemukan bahwa current ratio berpengaruh positif signifikan terhadap dividend payout ratio. Namun, hasil berbeda ditemukan oleh Tariq (2015) yang menyatakan bahwa current ratio berpengaruh negatif signifikan terhadap dividend payout ratio. Nerviana (2015) dan Deitiana (2013) menemukan bahwa tidak terdapat pengaruh signifikan current ratio terhadap dividend payout ratio. 
Institutional ownership merupakan porsi kepemilikan saham oleh pihak institusi seperti perusahaan lain atau pemerintah. Suatu institusi yang memegang saham memiliki pengaruh yang lebih besar dibandingkan individu termasuk dalam hal mengendalikan dan mengawasi kebijakan manajeman perusahaan. Penelitian Betania (2015) menemukan semakin besar porsi saham yang dimiliki oleh institusi akan meningkatkan besarnya dividen yang dibagi. Pihak institusi mampu memengaruhi manajeman dalam menentukan kebijakan dividen. Pada dasarnya investor lebih menyukai dividen yang dibagikan secara tunai. Hal ini sesuai dengan penelitian Moradi et., al. (2012) yang menemukan bahwa institutional ownership berpengaruh positif signifikan terhadap dividend payout ratio. Hasil berbeda ditemukan oleh Al Najjar (2016) serta Putri dan Nasir (2006) yang menyatakan institutional ownership berpengaruh negatif signifikan terhadap dividend payout ratio. Sedangkan menurut Wardhana (2013), institutional ownership tidak berpengah terhadap dividend payout ratio.

Modal perusahaan dalam menjalankan operasionalnya dapat bersumber dari ekuitas dan hutang. Salah satu fungsi manajemen keuangan dalam perusahaan adalah menetapkan kebijakan pendanaan seperti kebijakan hutang. Kebijakan hutang suatu perusahaan dapat dilihat dari debt to equity ratio. Kebijakan hutang dapat memengaruhi kebijakan dividen, semakin besar hutang perusahaan akan menyebabkan kemampuan untuk membayar dividen semakin kecil karena keuntungan perusahaan berkurang dengan adanya biaya hutang perusahaan ( $\mathrm{Al}$ Najjar, 2016). Hasil penelitian Al Najjar (2016) menunjukkan bahwa debt to equity ratio berpengaruh negatif signifikan terhadap dividend payout ratio. Hasil serupa ditemukan oleh Nerviana (2015), debt to equity ratio yang tinggi secara signifikan dapat menurunkan dividend payout ratio. Hasil sebaliknya ditemukan oleh Moradi et., al. (2012) yang menyatakan bahwa debt to equity ratio berpengaruh positif signifikan terhadap dividend payout ratio. Penelitian yang dilakukan oleh Komala dan Nugroho (2013), Anggraini dkk (2010) serta Putri dan Nasir (2006) memperoleh hasil debt to equity ratio tidak berpengaruh signifikan terhadap dividend payout ratio.

Kebijakan hutang perusahaan dapat dipengaruhi oleh berbagai faktor, salah satunya faktor internal perusahaan. Faktor internal perusahaan seperti profitabilitas, firm size, likuiditas dan kepemilikan institusi diduga mampu memengaruhi debt to equity ratio yang pada akhirnya dapat berpengaruh pada dividend payout ratio. Profitabilitas yang tinggi dapat menurunkan kebutuhan hutang perusahaan. Gharaibeh (2015) menunjukkan bahwa secara statistik return on equity memiliki hubungan negatif yang signifikan dengan debt to equity ratio. Keuntungan perusahaan yang meningkat akan menurunkan rasio hutang perusahaan. Penelitian tersebut mendukung hasil penelitian Tarazi (2013) yang menyatakan bahwa perusahaan dengan profitabilitas yang lebih tinggi cenderung menggunakan dana internal daripada hutang. Dengan kata lain,perusahaan dengan profitabilitas yang tinggi justru tingkat hutangnya rendah, karena perusahaan yang profitabilitasnya tinggi memiliki sumber dana yang sangat baik Ghi dan Ba (2015). Hasil penelitian lain dikemukakan oleh Hermuningsih (2001) yang menyatakan bahwa return on equity berpengaruh positif signifikan terhadap dept to equity ratio. Hasil penelitian tersebut didukung oleh Dharmawan (2015). 
Menurut Putri dan Nasir (2006), profitabilitas tidak berpengaruh signifikan terhadap kebijakan hutang.

Acaravci (2015) menyatakan bahwa firm size berpengaruh negatif signifikan terhadap debt to equity ratio. Perusahaan cenderung menggunakan equity untuk membiayai operasionalnya daripada menggunakan hutang. Hasil tersebut konsisten dengan penelitian Tarazi (2013) yang menyimpulkan bahwa terdapat pengaruh yang negatif dan signifikan antara firm size dengan leverage. Hasil penelitian tersebut didukung oleh Akinyomi dan Olagunju (2013) serta Jahanzeb dan Bajuri (2014) yang menyatakan bahwa ukuran perusahan berpengaruh negatif derhadap struktur modal. Penyataan lain menyatakan bahwa prubahan firm size memiliki hubungan positif signifikan dengan ratio hutang perusahaan (Gharaibeh, 2015). Menurut penelitian yang dilakukan Tariq (2015) ditemukan bahwa firm size berhubungan secara positif terhadap leverage. Penelitian tersebut menemukan bukti-bukti yang menunjukan perusahaanperusahaan besar di Pakistan cenderung memiliki tingkat leverage yang lebih besar dibandingkan perusahaan yang kecil. Hasil tersebut konsisten dengan penelitian Dhanrmawan (2015) dan Hermuningsih (2012). Hasil lain ditemukan oleh Al Khatib (2012) yaitu firm size dan debt to equity ratio tidak terdapat pengaruh yang signifikan.

Peusahaan yang memiliki current ratio tinggi memiliki kemampuan untuk memenuhi kewajiban atas hutang lancarnya. Likuiditas perusahaan yang tinggi akan memberi kesempatan perusahaan untuk mengelola aset lancarnya sehingga kebutuhan terhadap hutang akan menurun dan mengakibatkan rasio hutang terhadap modal perusahaan semakin kecil. Penelitian yang dilakukan oleh Masnoon dan Saeed (2014), Jahanzeb dan Bajuri (2014) serta Sarlija dan Harc (2012) yang menyatakan bahwa current ratio berpengaruh negatif terhadap signifikan terhadap debt to equity ratio. Namun, hasil lain ditemukan oleh Gharaibeh (2015) yang menyatakan bahwa perubahan posisi likuiditas perusahaan memiliki pengaruh positif dan signifikan terhadap rasio hutang perusahaan.

Institutional ownership yang tinggi mencerminkan bahwa porsi saham yang dimiliki institusi relatif besar. Institusi biasanya dapat menguasai mayoritas saham perusahaan sehingga institusi memiliki pengaruh yang lebih besar dibandingkan pemegang saham individu khususnya dalam mengendalikan dan mengawasi tindakan manajemen perusahaan termasuk dalam kebijakan hutang. Betania (2015) menyatakan bahwa institutional ownership berpengaruh negatif signifikan terhadap debt to equity ratio, hal ini mengindikasikan bahwa semakin besar saham yang dimiliki institusi berpengaruh memperkecil debt to equity ratio, hal ini dikarenakam peranan pihak institusi dalam memonitor kinerja manajemen relatif kuat. Hasil tersebut mendukung penelitian Tariq (2015) yang menyatakan bahwa institutional ownership berpengaruh negatif terhadap debt to equity ratio. Hasil berbeda ditemukan oleh Moradi et al. (2012) yang menyatakan bahwa institutional ownership berpengaruh positif terhadap debt to equity ratio. Hasil lain ditemukan oleh Putri dan Nasir (2006), kepemilikan institusional secara statistik tidak berpengaruh signifikan terhadap kebijakan modal. 
Tabel 1

Data Rata-rata Return on Equity, Firm Size, Current Ratio, Institutional Ownership, Debt to Equity Ratio dan Dividend Payout Ratio

Pada Perusahaan Manufaktur yang Terdaftar pada Bursa Efek Indonesia periode Tahun 2012-2014

\begin{tabular}{|l|c|c|c|}
\hline \multicolumn{1}{|c|}{ Variabel } & \multicolumn{3}{c|}{ Tahun } \\
\cline { 2 - 4 } & $\mathbf{2 0 1 2}$ & $\mathbf{2 0 1 3}$ & $\mathbf{2 0 1 4}$ \\
\hline Return on equity (\%) & 26,51 & 24,08 & 21,80 \\
\hline Firm size & 15,43 & 15,61 & 15,73 \\
\hline Current ratio (x) & 2,38 & 2,28 & 2,11 \\
\hline Institutional Ownership (\%) & 66,11 & 64,37 & 64,64 \\
\hline Debt to equity ratio $(\mathrm{x})$ & 0,89 & 0,80 & 0,87 \\
\hline Dividend payout ratio (\%) & 23,60 & 27,32 & 32,45 \\
\hline
\end{tabular}

Sumber : Data laporan keuangan yang dimuat dalam ICMD 2015

Selama periode pengamatan dari tahun 2012-2014 pada perusahaan manufaktur yang terdaftar pada Bursa Efek Indonesia dapat diketahui bahwa perubahan nilai pembayaran dividen, struktur modal, profitabilitas, firm size, likuiditas dan kepemilikan institusitidak seragam. Hal ini menunjukkan adanya fenomena gap pada peruashaan manufaktur di Indonesia. Penelitian terdahulu mengenai pengaruh variabel return on equity, firm size, current ratio dan institutional ownership terhadap debt to equity ratio dan dampaknya terhadap dividend payout ratio menunjukkan hasil yang berbeda dan tidak konsisten sehingga terjadi research gap. Fenomena gap dan research gap tersebut menjadi alasan untuk melakukkan penelitian lebih lanjut mengenai faktor-faktor yang memengaruhi dividend payout ratio. Penelitian ini dilakukan untuk menguji pengaruh variabel return on equity, firm size, current ratio dan institutional ownership terhadap dividend payout ratio dengan debt to equity ratio sebagai variabel intervening. Pengematan dilakukan pada perusahaan manufaktur yang terdaftar di Bursa Efek Indonesia periode tahun 2012-2014.

\section{TELAAH PUSTAKA DAN PENGEMBANGAN HIPOTESIS}

\section{Pengaruh Return on Equity terhadap Debt to Equity Ratio}

Hasil penelitian Gharaibeh (2015) menunjukkan bahwa secara statistik return on equity memiliki hubungan negatif yang signifikan dengan debt to equity ratio. Keuntungan perusahaan yang meningkat akan menurunkan kebutuhan perusahaan akan dana yang bersumber dari hutang, sehingga akan menurunkan rasio hutang perusahaan. Penelitian tersebut mendukung hasil penelitian Tarazi (2013) yang menyatakan bahwa perusahaan dengan profitabilitas yang lebih tinggi cenderung menggunakan dana internal daripada hutang. Menurut Ghi dan $\mathrm{Ba}$ (2015), perusahaan dengan profitabilitas yang tinggi justru tingkat hutangnya rendah, karena perusahaan memiliki sumber dana internal yang sangat baik. Perusahaan cenderung menggunakan internal finance dalam bentuk laba ditahan untuk membiayai operasionalnya.

$H_{1} \quad$ : return on equity berpengaruh negatif terhadap debt to equity ratio. 


\section{Pengaruh Firm Size terhadap Debt to Equity Ratio}

Acaravci (2015) menemukan bahwa firm size berpengaruh negatif terhadap debt to equity ratio. Perusahaan besar lebih cenderung memilik menggunakan ekuitas untuk membiayai operasionalnya daripada menggunakan hutang. Hsail tersebut mendukung penelitian Tarazi (2013) yang menyimpulkan bahwa terdapat pengaruh negatif dan signifikan antara firm size dengan leverage. Akinyomi dan Adebayo Olagunju (2013) serta Jahanzeb dan Bajuri (2014) menyatakan bahwa ukuran perusahaan mempunyai pengaruh negatif terhadap struktur modal.

$\mathrm{H}_{2}$ : firm size berpengaruh negatif terhadap debt to equity ratio

\section{Pengaruh Current Ratio terhadap Debt to Equity Ratio}

Perusahaan yang mempunyai likuiditas tinggi akan cenderung menurunkan total hutang. Likuiditas mempunyai pengaruh negatif terhadap det to equity ratio. Hasil kajian empiris yang mendukung adalah Jahanzeb dan Bajuri; Jamal et al. (2013); serta Sarlija dan Harc (2012) yang mengatakan bahwa likuiditas berpengaruh negatif terhadap leverage atau current ratio secara signifikan berpengaruh negatif terhadap leverage.

$\mathrm{H}_{3} \quad$ : current ratio berpengaruh negatif terhadap debt to equitty ratio.

\section{Pengaruh Institutional Ownership terhadap Debt to Equity Ratio}

Jensen dan Meckling (1976) dalam Jamal et al. Mengemukakan teori keagenan yang menjelaskan bahwa kepentingan manajemen dan kepentingan pemegang saham sering kali bertentangan, sehingga bisa menyebabkan terjadinya konflik di antara keduanya. Institutional ownership yang tinggi membuat pengawasan pemegang saham terhadap manajer semakin ketat, sehingga akan membatasi kebijakan manajer dalam penggunaan hutang. Betania (2015) menyatakan institutional ownership berpengaruh negatif signifikan terhadap debt to equity ratio. Hal ini disebabkan adanya pengawasan yang lebih ketat dari pemegang saham institusi sehingga dapat membatasi manajer dalam membuat keputusan pendanaan. Penelitian tersebut sejalan dengan Tariq (2015) dan AlNajjar (2010) yang menunjukkan hasil institutional ownership berpengaruh negatif signifikan terhadap debt to equity ratio.

$\mathrm{H}_{4} \quad$ : institutional ownership berpengaruh negatif terhadap debt to equity ratio

\section{Pengaruh Return on Equity terhadap Dividend Payout Ratio}

Signalilng theory menyatakan bahwa profitabilitas memiliki pengaruh positif terhadap pembayaran dividen tunai (Tariq, 2015). Hasil penelitian Nerviana (2015) menyatakan bahwa variabel return on equity memiliki pengaruh positif dan signifikan terhadap dividend payout ratio. Arshad et al. (2013) menemukan bahwa return on equity secara signifikan berpengaruh positif terhadap dividend payout ratio. Hal ini berarti dengan addanya peningkatan keuntungan perusahaan yang ditandai dengan tingginya return on equity dapat meningkatkan peluang untuk pembayaran dividen. Hasil serupa diperoleh dari penelitian Than Nha Ghi (2015) serta Hejazi dan Moshtaghin (2014) yang 
menemukan adanya pengaruh positif dan signifikan dari variabel return on equity terhadap dividend payout ratio.

$H_{5} \quad$ : return on equity berpengaruh positif terhadap dividend payout ratio

\section{Pengaruh Firm Size terhadap Dividend Payout Ratio}

Hejazi dan Moshtaghin (2014) menyatakan perusahaan yang besar cenderung membagikan dividen yang lebih besar daripada perusahaan kecil, karena perusahaan yang memiliki asset besar lebih mudah memasuki pasar modal, sedangkan perusahaan yang memiliki asset sedikit akan cenderung membagikan dividen yang rendah karena laba dialokasikan pada laba ditahan untuk menambah aset perusahaan. Myron Gordon dan J. Litnner dengan teorinya Bird in the Hand Theory mengemukakan bahwa para pemegang saham lebih suka jika earning dibagikan dalam bentuk dividen daripada ditahan (retained earning). Alasan mereka adalah bahwa pembayaran dividen merupakan penerimaan yang lebih pasti dibandingkan dengan capital gain. Hasil penelitian Al-Najjar (2016) dan Mehta (2012) mendukung hal tersebut karena keduanya menemukan bahwa firm size berpengaruh positif dan signifikan terhadap dividend payout ratio. Semakin besar suatu perusahaan, semakin besar pula rasio dividen yang akan dibagikan.

$\mathrm{H}_{6} \quad$ : firm size berpengaruh positif terhadap dividend payout ratio

\section{Pengaruh Current Ratio terhadap Dividend Payout Ratio}

Wasike (2015) menyatakan bahwa likuiditas suatu perusahaan merupakan faktor penting yang diperhatikan dalam kebijakan dividen. Likuiditas yang baik pada suatu perusahaan akan meningkatkan kemampuan perusahaan tersebut dalam membayar dividen. Hal tersebut didukung oleh bird in the hand theory yang menyatakan bahwa pemegang saham lebih menyukai dividen yang dibagikan secara tunai, sehingga ketika perusahaan mempunyai likuiditas yang tinggi maka dividend payout ratio akan meningkat. Penelitian Ahmed (2015) dan Mehta (2012) menunjukkan hasil likuiditas berpengaruh positif dan signifikan terhadap dividend payout ratio.

$H_{7} \quad$ : current ratio berpengaruh positif terhadap dividend payout ratio

\section{Pengaruh Institutional Ownership terhadap Dividend Payout Ratio}

Agency theory menyatakan bahwa perusahaan dengan kepemilikan saham institusi yang tinggi akan melakukan monitoring agents dengan harapan pembagian dividen yang lebih besar (Putri dan Nasir, 2006). Semakin besar institutional ownership akan meningkatkan dividend payout ratio. Hasil penelitian Al-Nawaiseh (2013) menunjukkan bahwa institutional ownership berpengaruh positif terhadap dividend payout ratio.

$H_{8} \quad$ : institutional ownership berpengaruh negatif terhadap dividend payout ratio

\section{Pengaruh Debt to Equity Ratio terhadap Dividend Payout Ratio}

Debt to equity ratio mencerminkan proporsi hutang jangka panjang dengan modal sendiri (ekuitas). Hutang yang semakin besar menyebabkan beban perusahaan menjadi besar karena biaya hutang yang harus ditanggung. Semakin besar hutang akan menyebabkan prioritas perusahaan untuk membayar dividen 
akan semakin kecil karena keuntungan perusahaan berkurang dengan adanya biaya hutang perusahaan (Moradi et al. 2012). Moradi et al., (2012) menemukan bahwa DER berpengaruh signifikan negatif terhadap DPR. Penelitian yang dilakukan oleh Nerviana (2015) dan Betania (2015) juga menunjukkan hasil sama. $H_{9} \quad$ : debt to equity ratio berpengaruh negatif terhadap dividend payout ratio

\section{Debt to Equity Ratio Memediasi Pengaruh Return on Equity terhadap Dividend Payout Ratio}

Gharaibeh (2015) menunjukkan bahwa return on equity berpengaruh negatif signifikan terhadap debt to equity ratio. Debt to equity ratio mencerminkan proporsi hutang jangka panjang dengan modal sendiri (ekuitas). Besarnya hutang suatu perusahaan akan menyebabkan prioritas perusahaan untuk membayar dividen akan semakin kecil karena keuntungan perusahaan berkurang akibat adanya biaya hutang perusahaan (Moradi et al. 2012). Bird in the hand theory menyatakan investor lebih menyukai dividen tunai daripada menunggu pengembalian dari keuntungan modal. Hasil penelitian Ghi dan Ba (2015) menyatakan bahwa variabel return on equity memiliki pengaruh positif signifikan terhadap dividend payout ratio. Hasil yang sama juga ditemukan oleh Wasike (2015) dan Arshad et al. (2013).

$H_{10}$ : debt to equity ratio mampu memediasi pengaruh return on equity terhadap dividend payout ratio

\section{Debt to Equity Ratio Memediasi Pengaruh Firm Size terhadap Dividend Payout Ratio}

Perusahaan besar akan membutuhkan lebih sedikit ana dari eksternal berupa hutang daripada perusahaan kecil. Sehingga dapat dikatakan firm size memiliki pengaruh yang negatif terhadap debt to equity ratio. Investor mempunyai kecenderungan tidak menyukai hutang perusahaan, karena dengan hutang yang besar akan menurunkan besarnya dividen (Jensen et al., 2002). Rasio hutang yang tinggi membuat perusahaan memiliki kewajiban biaya modal yang tinggi sehingga mengurangi besarnya laba yang dapat dibagikan dalam bentuk dividen. Debt to equity ratio memilliki pengaruh negatif terhadap dividend payout ratio (Al-Najjar, 2006). Mehta (2012) menyatakan bahwa perusahaan berukuran besar cenderung membayar dividen lebih tinggi sedangkan perusahaan berukuran lebih kecil cenderung membayar dividen lebih sedikit. Firm size berpengaruh positif terhadap dividend payout ratio karena perusahaan besar memilikki kapasitas modal yang tinggi atas aktivitas yang dilakukannya (Hejazi dan Moshtaghin, 2014).

$H_{11}$ : debt to equity ratio mampu memediasi pengaruh firm size terhadap dividend payout ratio

\section{Debt to Equity Ratio Memediasi Pengaruh Current Ratio terhadap Dividend Payout Ratio}

Penelitian Jahanzeb dan Bajuri (2014) menemukan bahwa current ratio berpengauh negatif signifikan terhadap debt to equity ratio. Investor mempunyai kecenderungan utidak menyukai hutaang perusahaan, karema dengan hutang yang 
besar akan menurunkan besarnya dividen (Jensen et al., 2002). Semakin besar hutang akan menyebabkan prioritas perusahaan untuk membayar dividen semakin kecil karena keuntungan perusahaan berkurang akibat adanya biaya modal perusahaan (Moradi et al., 2012), sehingga dapat dikatakan bahwa debt to equity ratio berpengaruh negatif terhadap dividend payout ratio. Tariq (2015) mengemukakan bahwa likuiditas perusahaan mampu segara signifikan memengaruhi kebijakan pendanaan maupun kebijakan dividen. Penelitian tersebut menemukan pengaruh negatif current ratio terhadapp debt to equity ratio, serta pengaruh positif dari current ratio terhadap dividend payout ratio. Hasil penelitian Wasike (2015) dan Ahmed (2015) menunjukkan bahwa current ratio berpengaruh positiferhadap dividend payout ratio.

$H_{12}$ : debtt to equity ratio mampu memediasi pengaruh current ratio terhadap dividend payout ratio

\section{Debt to Equity Ratio Memediasi Pemgaruh Institutional Ownership terhadap Dividend Payout Ratio}

Berdasarkan agency theory, institutional ownership berpengaruh negatif terhadap debt to equity ratio. Dalam penelitian Tariq (2015) dan Betania (2015) ditemukan bahwa institutional ownership berpengaruh negatif signifikan terhadap debt to equity ratio. Hasil penelitian Moradi et al. (2012) menunjukkan bahwa debt to equity ratio berpengaruh negatif signifikan terhadap dividend payout ratio. Dalam penelitian yang sama, ditemukan hasil institutional ownership berpengaruh positif signifikan terhadap dividend payout ratio. Variabel debt to equity ratio diprediksi mampu memediasi pengaruh institutional ownership terhadap dividend payout ratio. Hasil penelitian Putri dan Nasir (2006) menunjukkan bahwa debt to equity ratio mampu memediasi pengaruh institutional ownership terhadap dividend payout ratio. Hasil penelitian tersebut didukung oleh penelitian yang dilakukan Wardhana (2013) dan Betania (2015).

$H_{13}$ : debt to equity ratio mampu memediasi pengaruh institutional ownership terhadap dividend payout ratio

\section{METODE PENELITIAN}

\section{Jenis dan Variabel Penelitian}

Penelitian dilakukan untuk menguji dan menganalisis faktor-faktor yang mempengaruhi keputusan dividen. Data yang digunakan dalam penelitian ini adalah data tahunan dari return on equity, firm size, current ratio, institutional ownership, debt to equity ratio dan dividend payout ratio. Periode pengamatan dilakukan dari tahun 2012 hingga 2014. Data dalam penelitian ini bersumber dari ICMD 2015 yang kemudian disalin untuk diolah dan dianalisis. Pemilihan periode pengamatan tersebut didasari alasan kelengkapan data, karena untuk tahun-tahun berikutnya masih banyak data yang not available (n.a.).

Variabel yang digunakan dalam penelitian ini dijelaskan melalui Tabel 2. sebagai berikut : 
Tabel 2.

Variabel Penelitian

\begin{tabular}{|c|c|c|c|}
\hline VARIABEL & DEFINISI & SKALA & $\begin{array}{c}\text { RUMUS PENGUKURAN } \\
\text { (SUMBER) }\end{array}$ \\
\hline \multicolumn{4}{|l|}{ DEPENDENT } \\
\hline $\begin{array}{l}\text { Dividend Payout } \\
\text { Ratio (DPR) }\end{array}$ & $\begin{array}{l}\text { Perbandingan antara } \\
\text { dividend per share } \\
\text { dengan earning per } \\
\text { share }\end{array}$ & Rasio & $\begin{array}{l}\frac{\text { Dividend Per Share }}{\text { Earning Per Share }} \times 100 \% \\
\quad \text { (Robert Ang, 1997) }\end{array}$ \\
\hline \multicolumn{4}{|l|}{ INTERVENING } \\
\hline $\begin{array}{l}\text { Debt to Equity } \\
\text { Ratio (DER) }\end{array}$ & $\begin{array}{l}\text { Perbandingan antara } \\
\text { total hutang dengan total } \\
\text { ekuitas }\end{array}$ & Rasio & $\begin{array}{c}\text { Total Debts } \\
\text { Total Shareholders Equity } \\
\text { (Robert Ang, 1997) }\end{array}$ \\
\hline \multicolumn{4}{|l|}{ INDEPENDEDNT } \\
\hline $\begin{array}{l}\text { Return On Equity } \\
\text { (ROE) }\end{array}$ & $\begin{array}{l}\text { Perbandingan antara } \\
\text { laba bersih perusahaan } \\
\text { dengan ekuitas yang } \\
\text { dimiliki oleh perusahaan }\end{array}$ & Rasio & $\begin{array}{l}\frac{\text { Earning After Tax }}{\text { Shareholders Equity }} \times 100 \% \\
\quad \text { (Robert Ang, 1997) }\end{array}$ \\
\hline Firm Size (FS) & $\begin{array}{l}\text { Logaritma natural dari } \\
\text { total aktiva perusahaan }\end{array}$ & Rasio & $\begin{array}{c}\text { Ln Total Assets } \\
\text { (Hejazi \& Moshtaghin, 2014) } \\
\text { (Deesomsak et al., 2004) }\end{array}$ \\
\hline Current Ratio (CR) & $\begin{array}{l}\text { Perbandingan antara } \\
\text { aktiva lancar dengan } \\
\text { hutang lancar }\end{array}$ & Rasio & $\begin{array}{c}\text { Current Assets } \\
\begin{array}{c}\text { Current Liabilities } \\
\text { (Robert Ang, 1997) }\end{array}\end{array}$ \\
\hline $\begin{array}{l}\text { Institutional } \\
\text { Ownership (IO) }\end{array}$ & $\begin{array}{l}\text { Jumlah saham yang } \\
\text { dimiliki oleh institusi }\end{array}$ & Rasio & $\begin{array}{c}\text { Total Saham institusi } \\
\text { Total Saham yang beredar } \\
\text { (Tariq 2015) }\end{array}$ \\
\hline
\end{tabular}

Sumber : Ang (1997), Hejazi dan Moshtaghin (2014), Deesomsak et al. (2004), Tariq (2015)

\section{Metode Analisis}

Metode analisis yang digunakan dalam penelitian ini adalah metode analisis regresi berganda dan kemudian dikembangkan lebih lanjut menjadi model analisis jalur. Keterbatasan jumlah sampel penelitian menjadi alasan penelitian ini menggunakan pendekatan Partial Least Squares (PLS). Pendekatan PLS adalah ditribution free (Ghozali, 2014). Penelitian ini menggunakan uji multikolinieritas, uji koefisien determinasi dan uji signifikansi untuk menilai goodness of fit model.

\section{HASIL PENELITIAN}

\section{Uji Multikolinieritas}

Pengujian terhadap gejala multikolinieritas ini dilakukan untuk mengetahui apakah terdapat korelasi/hubungan yang kuat antar variabel-variabel independen dalam model persamaan regresi. Adanya multikolinieritas dalam model persamaan regresi yang digunakan akan mengakibatkan ketidakpastian 
estimasi, sehingga mengarahkan kesimpulan yang menerima hipotesis nol (Ghozali, 2014). Uji multikolinieritas dalam penelitian ini dilakukan dengan perhitungan nilai variance inflation factor (VIF). hasil dari uji multikolinieritas dapat dilihat dari Tabel 2 berikut :

Tabel 3.

Hasil Uji Multikolinieritas

\begin{tabular}{|c|c|c|}
\hline Variabel Independent & \multicolumn{2}{|c|}{ Variance Inflation Factor (VIF) } \\
\cline { 2 - 3 } & DER & DPR \\
\hline ROE & 1,183 & 1,424 \\
\hline FS & 1,118 & 1,121 \\
\hline CR & 1,096 & 1,588 \\
\hline IO & 0,182 & 1,304 \\
\hline DER & & 1,957 \\
\hline
\end{tabular}

Sumber : Output analisis data

Hasil uji multikolinieritas menunjukkan bahwa semua variabel independen dari model yang diteliti tidak terdapat multikolinieritas yang ditunjukkan oleh nilai VIF yang jauh dibawah 10. Hasil ini menunjukkan bahwa model dalam penelitian ini layak untuk digunakan.

Tabel 4.

Correlation Matrix

\begin{tabular}{|c|c|c|c|c|c|c|}
\hline Variabel & ROE & FS & CR & IO & DER & DPR \\
\hline ROE & 1,000 & $-0,207$ & $-0,194$ & 0,277 & 0,386 & $-0,014$ \\
\hline FS & $-0,207$ & 1,000 & $-0,104$ & $-0,278$ & 0,016 & 0,380 \\
\hline CR & $-0,194$ & $-1,04$ & 1,000 & 0,137 & $-0,600$ & 0,394 \\
\hline IO & 0,277 & $-0,278$ & 0,137 & 1,000 & $-0,212$ & 0,141 \\
\hline DER & 0,386 & 0,016 & $-0,600$ & $-0,212$ & 1,000 & $-0,451$ \\
\hline DPR & $-0,014$ & 0,380 & 0,394 & 0,141 & $-0,451$ & 1,000 \\
\hline
\end{tabular}

Sumber : Output analisis data

Tabel 4 menunjukkan besaran korelasi antar variabel independen dan terlihat bahwa hanya variabel CR yang mempunyai korelasi cukup tinggi dengan variabel DER dengan tingkat korelasi sebesar $-0,600$ atau sekitar $60 \%$. Korelasi antara variabel CR dengan DER masih dibawah 80\%, maka dapat dikatakan bahwa tidak terjadi multikolinieritas yang serius. Jika nilai koefisien $<0.80$, aka tidek terdapat multikolinieritas yang berbahaya dalam model penelitian (Ghozali, 2014). Sehingga, berdasarkan hasil pengujian dapat disimpulkan bahwa tidak terjadi multikolinieritas antar variabel dan model dinyatakan memenuhi syarat untuk diteliti.

\section{Koefisien Determinasi}

Koefisien determinasi $\left(R^{2}\right)$ pada intinya mengukur seberapa jauh kemampuan model dalam menerangkan variasi variabel dependen. Nilai koefisien determinasi adalah di antara nol dan satu. Nilai $R^{2}$ yang kecil berarti kemampuan 
variabel-variabel independen dalam menjelaskan variasi variabel dependen amat terbatas. Nilai yang mendekati satu berarti variabel-variabel independen memberikan hampir semua informasi yang dibutuhkan untuk memrediksi variassi variabel dependen, sedangkan nilai adjusted $R$ square unruk melihat model mana yang paling baik digunakan (the best fit of model) (Ghozali, 2014). Nilai koefisien determinasi dari penelitian ini disajikan dalam Tabel 4 sebagai berikut :

Tabel 5.

Koefisien Determinasi

\begin{tabular}{|c|c|c|}
\hline Variabel dependent & R Square & Adjuusted R Square \\
\hline DER & 0,489 & 0,456 \\
\hline DPR & 0,470 & 0,426 \\
\hline
\end{tabular}

Sumber : Output analisis data

Nilai adjusted $R$ square sebesar 0,456 untuk variabel dependen DER menunjukkan bahwa variasi variabel independen mampu menjelaskan 45,6\% variasi variabe dependen, sedangkan sisanya yaitu sebesar 54,4\% dijelaskan oleh variabel lain di luar variabel independen. Nilai adjusted $R$ square sebesar 0,426 untuk variabel dependen DPR menunjukkan bahwa variasi variabel independen mampu menjelaskan $42,6 \%$ wariasi variabel dependen, sedangkan sisanya yaitu sebesar 57,4\% dijelaskan oleh variabel lain di luar variabel independen. Dari hasil tersebut dapat disimpulkan bahwa kedua model strukturak cukup baik (moderat) karena memiliki hasil $R$ square di atas 0,33 sehingga kedua model regresii dalam penelitian ini dinyatakan layak untuk diteliti.

\section{Uji Signifikansi (Uji t)}

Uji statistik t pada dasarnya menunjukkan seberapa jauh pengaruh satu variabel penjelas/independen secara individual dalam menerangkan variasi variabel dependen. Nilai t statistik akan dibandingkan dengan nilai t tabel pada tingkat signifikansi tertentu. Nilai t statistik harus lebih besar daripada t tabel. Penelitian ini menggunakan tingkat signifikansi 5\% sehingga t statistik harus lebih besar dari 1,967. Hasil uji t disajikan dalam Tabel 6 sebagai berikut :

Tabel 6.

Uji t

\begin{tabular}{|c|c|c|c|c|c|}
\hline Variabel & Koefisien & Mean & Std Error & T & P Value \\
\hline DER & 0,489 & 0,526 & 0,096 & 5,098 & 0,000 \\
\hline DPR & 0,470 & 0,524 & 0,075 & 6,226 & 0,000 \\
\hline
\end{tabular}

Sumber : Output analisis data

Tabel 6 menunjukkan bahwa semua variabel memiliki t hitung yang lebih besar dari t tabel $(1,967)$ dan tingkat signifikansi yang lebih kecil dari 0,05 . Hal ini menunjukkan bahwa baik model regresi pertama maupun model regresi kedua dinyatakan layak untuk diteliti. 


\section{Pengujian Hipotesis}

Hasil analisis jalur (path analysis) data dengan menggunakan software SMART PLS juga dapat disajikan dalam bentuk Tabel 7 sebagai berikut :

Tabel 7.

Path Coefficients (Mean, Std Error, T-Value)

\begin{tabular}{|l|c|c|c|c|c|}
\hline \multicolumn{1}{|c|}{ Pengaruh } & Koefisien & Mean & $\begin{array}{c}\text { Std. } \\
\text { Error }\end{array}$ & T Statistics & P Value \\
\hline ROE > DER & 0,351 & 0,315 & 0,198 & 1,774 & 0,077 \\
\hline FS > DER & $-0,033$ & $-0,045$ & 0,067 & 0,498 & 0,619 \\
\hline CR > DER & $-0,501$ & $-0,510$ & 0,060 & 8,310 & 0,000 \\
\hline IO > DER & $-0,250$ & $-0,249$ & 0,064 & 3,900 & 0,000 \\
\hline ROE > DPR & 0,263 & 0,235 & 0,196 & 1,344 & 0,180 \\
\hline FS > DPR & 0,491 & 0,504 & 0,085 & 5,738 & 0,000 \\
\hline CR > DPR & 0,248 & 0,267 & 0,142 & 1,753 & 0,080 \\
\hline IO > DPR & 0,088 & 0,098 & 0,074 & 1,180 & 0,239 \\
\hline DER > DPR & $-0,392$ & $-0,353$ & 0,159 & 2,468 & 0,014 \\
\hline
\end{tabular}

Sumber : Output olah data sekunder

Penelitian ini menggunakan analisis regresi berganda yang kemudian dikembangkan lebih lanjut menjadi model analisis jalur. Persamaan regresi yang dapat disususn berdasarkan Tabel 7 untuk penelitian ini adalah sebagai berikut :

$D E R=0,351 R O E-0,033 F S-0,501 C R-0,250 I O$

$D P R=0,263 R O E+0,491 F S+0,248 C R+0,088 I O-0,392 D E R$

Mediasi variabel intervening pada pengaruh variabel independen terhadap variabel dependen dapat digambarkan sebagai berikut :

Gambar 1.

Analisi Jalur

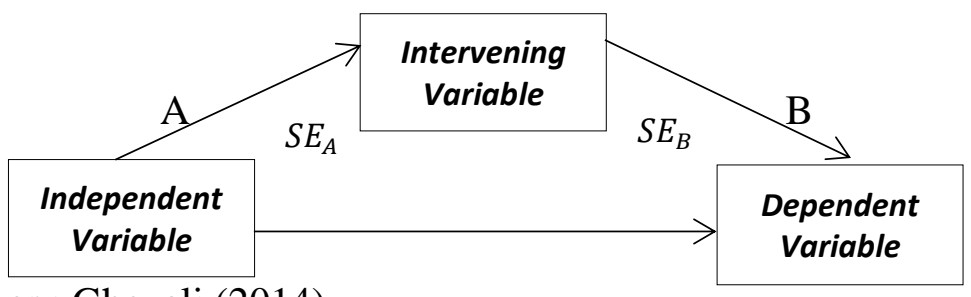

Sumber : Ghozali (2014)

Pengujian mediasi dilakukan dengan menggunakan sobel test dan diperoleh hasil sebagai berikut : 
Tabel 8.

Sobel Test

\begin{tabular}{|l|c|c|c|c|r|}
\hline \multicolumn{1}{|c|}{ PENGARUH VARIABEL } & $\mathbf{A}$ & $\mathbf{B}$ & $\boldsymbol{S E}_{\boldsymbol{A}}$ & $\boldsymbol{S E}_{\boldsymbol{B}}$ & $\boldsymbol{t}_{\text {statistics }}$ \\
\hline ROE terhadap DPR melalui DER & 0,351 & $-0,392$ & 0,198 & 0,159 & $-1,439$ \\
\hline FS terhadap DPR melalui DER & $-0,033$ & $-0,392$ & 0,067 & 0,159 & 0,483 \\
\hline CR terhadap DPR melalui DER & $-0,501$ & $-0,392$ & 0,060 & 0,159 & 0,364 \\
\hline IO terhadap DPR melalui DER & $-0,250$ & $-0,392$ & 0,064 & 0,159 & 2,085 \\
\hline
\end{tabular}

Sumber : Output olah data sekunder

\section{HASIL DAN PEMBAHASAN}

Hasil pengujian pada Tabel 7 menunjukkan bahwa return on equity tidak berpengaruh signifikan terhadap debt to equity ratio. Hasil ini sesuai dengan hasil penelitian Putri dan Nasir (2006) di mana asil penelitiannya menunjukkan bahwa return on equity tidak berpengaruh signifikan terhadap debt to equity ratio. Firm size juga tidak berpengaruh signifikan terhadap debt to equity ratio. Hasil ini sesuai dengan hasil penelitian Alkhatib (2012) di mana hasil penelitiannya menunjukkan bahwa firm size tidak berpengaruh signifikan terhadap debt to equity ratio.

Hasil pengujian pada Tabel 7 menunjukkan bahwa current ratio berpengaruh negatif signifikan terhadap debt to equity ratio. Hasil penelitian ini sesuang dengan pecking order theory yang menyatakan bahwa perusahaan memrioritaskan penggunaan ekuitas untuk membiayai operasional perusahaan. Hasil penelitian ini juga mendukung penelitian terdahulu yang dilakukan oleh Masnoon dan Saeed (2014); Jahanzeb dan Bajuri (2014); sarlija dan Harc (2012) serta Deesomsak et al., (2004). Institutional ownership juga berpangaruh negatif signifikan terhadap debt to equity ratio. Hasil penelitian ini sesuai dengan agqncy theory. Penelitian ini juga sejalan dengan penelitian yang dilakukan oleh Tariq (2015), Betania (2015) dan Al-Najjar (2010) yang menunjukkan hasil institutional ownership berpengaruh negatif signifikan terhadap debt to equity ratio.

Hasil pengujian pada Tabel 7 menunjukkan bahwa return on equity tidak berpengaruh signifikan terhadap dividend payout ratio. Hal ini sesuai dengan hasil penelitian Deitiana (2013) dan Rafique (2012). Hasil penelitian ini tidak konsisten dengan signaling theory yang dikembangkan oleh serta dengan bird in the hand theory. Current ratio tidak berpengaruh sihnifikan terhadap dividend payout ratio. Hasil penelitian ini sesuai dengan hasil penelitian Nerviana (2015) dan Deitiana (2013) yang menyatakan bahwa current ratio tidak berpengaruh signifikan terhadap dividend payout ratio. Hasil penelitian ini tidak konsisten dengan hasil penelitian Wasike (2013), Ahmed (2015) dan Mehta (2012). Hasil pengujian juga menunjukkan bahwa institutional ownership tidak berpengaruh terhadap dividend payout ratio. Hasil penelitian ini sesuai dengan hasil penelitian Wardhana (2013) yang menyatakan institutional ownership tidak berpengaruh signifikan terhadap dividend payout ratio. Hasil penelitian ini tidak konsisten dengan agency theory dan hasil penelitian Al-Nawaiseh (2013) serta Putri dan Nasir (2006).

Hasil pengujian pada Tabel 7 menunjukkan firm size berpengaruh positif signifikan terhadap dividend payout ratio. Hal ini relevan dengan bird in the hand theory di mana perusahaan yang besar cenderung membagikan dividen yang lebih 
tinggi. Hasil penelitian ini mendukung hasil penelitian yang dilakukan oleh AlNajjar (2016), Hejazi dan Moshtaghin (2014) serta Rafique (2012).

Hasil pengujian pada Tabel 7 menunjukkan debt to equity ratio berpengaruh negatif signifikan terhadap dividend payout ratio. Debt to equity ratio yang semakin rendah akan meningkatkan dividend payout ratio. Hasil penelitian ini relevan dengan balancing theory dan mendukung penelitian yang dilakukan oleh Al-Najjar (2016), Betania (2015) dan Nerviana (2015) yang menyatakan bahwa terdapat pengaruh negatif signifikan dari debt to equity ratio terhadap dividend payout ratio.

Tabel 8 menunjukkan bahwa debt to equity ratio tidak memediasi pengarug retur on equity terhadap dividend payout ratio dan pengaruh firm size terhadap dividend payout ratio. Tabel 8 juga menunjukkan bahwa debt tp equity ratio mampu memediasi pengaruh current ratio terhadap dividend payout ratio serta pengaruh institutional ownership terhadap dividend payout ratio.

\section{PENUTUP}

\section{Kesimpulan}

Dividend payout ratio dapat ditingkatkan dengan cara menurunkan besarnya debt to equity ratio dan meningkatkan besarnya firm size. Hal ini disebabkan karena debt to equity ratio berpengaruh negatif signifikan terhadap dividend payout ratio sedangkan firm size berpengaruh positif signifikan terhadap dividend payout ratio. Debt to equity ratio dapat diturunkan dengan cara meningkatkan besarnya current ratio dan institutional ownership, karena current ratio dan institutional ownership berpengaruh negatif signifikan terhadap debt to equity ratio. Debt to equity ratio sebagai variabel intervening mampu memediasi pengaruh current ratio terhadap dividend payout ratio serta pengaruh institutional ownership terhadap dividend payout ratio. Current ratio dan institutional ownership yang meningkat akan menurunkan debt to equity ratio yang kemudian dapat meningkatkan nilai dividend payout ratio.

\section{Saran}

Disarankan untuk penelitian yang akan datang agar memerluas objek penelitian tidak hanya terbatas pada perusahaan manufaktur tetapi seluruh perusahaan yang terdaftar di Bursa Efek Indonesia. Perode tahun penelitian juga perlu ditambah sehingga dapat terlihat perkembangan maasing-masing variabel dari tahun ke tahun agar hasil penelitian lebih akurat. Selain itu perlu juga menambah variabel lain seperti :cash free of flow, tangibility asset atau variabel lain yang memengaruhi debt to equity ratio dan dividend payout ratio agar hasil penelitian lebih sempurna yang ditandai dengan nilai $\mathrm{R}$ square menjasi lebih besar. Nilai R square yang lebih besar menandakan model lebih fit atau layak diteliti. 


\section{DAFTAR PUSTAKA}

Acaravci, Songul Kakilli. (2015). The Determinants of Capital Structure : Evidence from the Turkish Manufacturing Sector. International Journal of Economics and Financial. Issues 5 (1) : 158-71.

Ahmed, Ibrahim Elsiddig. (2015). Liquidity, Profitability and the Dividends Payout Policy. World Review of Business Research. Vol 5 (2) : 73-85.

Akinyomi, O. A., \& Adebayo, O. (2013) Determinants of Capital Structure in Nigeria. International Journal of Innovation and Applied Studies. Vol. 3 (4) : 999-1005.

Alkhatib, Khalid. (2012). The Determinants of Leverage of Listed Companies. International Journal of Business and Social Science. Vol. 3 (24) : 78-84.

Al-Najjar, Basil. (2016). The Effect of Ownership Structure on Dividend Policy: Evidence from Turkey. The International Journal of Business in Society. Vol. 16 (1).

Al-Nawaiseh, Mahmoud. (2013). Dividend Policy and Ownership Structure: An Applied Study on Industrial Companies in Amman Stock Exchange. Journal of Manajemen Research. Vol. 5 (2) : 83-106.

Ang, Robert. (1997). Buku Pintar pasar Modal Indonesia. Jakarta : Mediasoft Indonesia.

Arshad, Zeeshan, Yasir Akram, Maryam Amjad, and Usman Muhammad. (2013). Ownership Structure and Dividend Policy. Interdisciplinary Journal of Contemporary Research in Business. Vol. 5 (3) : 378-401.

Betania, Reni Purwani. (2015). Pengaruh Insider Ownership, Asset tangibility, Institutional Ownership dan Pertumbuhan Perusahaan terhadap Dividend Payout Ratio dengan Mediasi Debt to Equity Ratio. Tesis. Universitas Diponegoro.

Deesomsak, R., Padyal, K., \& Pescetto, G. (2004). The Determinants of Capital Structure : Evidence from the Asia Pacific Region. Journal of Multinational Financial Management. Vol. 14 (4-5) : 387-405.

Deitiana, Tita. (2013). Pengaruh Current Ratio, Return on Equity dan Total Asset Turn Over terhadap Dividend Payout Ratio dan Implikasi pada Harga Saham. Jurnal Bisnis dan Akuntansi. Vol. 15 (1) : 82-88.

Gharaibeh, Ahmad Mohammad Obeid. (2015). The Determinants of Capital Structure: Empirical Evidence from Kuwait. European Journal of Business, Economics and Accountancy. Vol. 3 (6) : 1-25.

Ghi, T. N., \& Ba. (2015). The Impact of Capital Structure and Financial Performance on Stock Return of the Firms in Hose. International Journal of Information Research and Review. Vol. 2 (06) : 734-737.

Ghozali, Imam. (2014). Structural Equation Modeling Metode Alternatif dengan Partial Least Squares (PLS). Edisi 4. Semarang : Badan Penerbit Universitas Diponegoro.

Hejazi, R. \& Moshtaghin. (2014). Impact of Agency Costs of Free Cash Flow on Dividend Policy and Leverage of Firms in Iran. The Open Business Journal. Vol. 3 : 14-21. 
Jahanzeb, A. \& Bajuri, N. H. (2014). Determinants of Capital Structure: Empirical Evidence from Pakistan. Middle-East Journal of Scientific Research. Vol. $22(2): 272-278$.

Jamal, A. A. A. et. al. (2013). Capital Structure Decisions: Evidence from Large Capitalized Companies in Malaysia. Interdisciplinary Journal of Contemporary Research in Business. Vol. 5 (5) : 30-49.

Jensen, M. C. (2012). Value Maximization, Stakeholder Theory, and the Corporate Objective Function. Business Ethics Quarterly. Vol. 12 (2) : 235-56.

Masnoon, M. \& Saeed, A. (2014). Capital Structure Determinants of KSE Listed Automobile Companies. European Scientific Journal. Vol. 10 (13) : 45161.

Mehta, A. (2012). An Empirical Analysis of Determinants of Dividend Policy Evidence from the UAE Companies. Global Review of Accounting and Finance. Vol. 3 (1) : 18-31.

Moradi, N. S., Aldin, M. M., Heyrani, F., \& Iranmahd, M. (2012). The Effect of Corporate Governance, Corporate Financing Decision and Ovwnership Structure on Firm Performance: A Panel Data Approach from Tehran Stock Exchange. International Journal of Economics and Finance. Vol. 4 (6) : 86-93.

Nerviana, Riri. (2015). The Effect of Financial Ratios and Company Size on Dividend Policy. The Indonesian Accounting Review. Vol. 5 (1) : 23-32.

Putri, I. F. \& Nasir, M. (2006). Analisis Persamaan Simultan Kepemilikan Manajerial, Kepemilikan Institusional, Risiko, Kebijakan Hutang dan Kebijakan Dividen dalam Perspektif Teori Keagenan. Simposium Nasional Akuntansi 9 Padang. 23-26.

Rafique, M. (2012). Factors Affecting Dividend Payout: Evidence From Listed Non-Financial Firms of Karachi Stock Exchange. Business Management Dynamics. Vol. 1 (11) : 76-92.

Sarlija, N. \& Harc, M. (2012). The Impact of Liquidity on the Capital Structure: A Case Study of Croatian Firm. Business Systems Research. Vol. 3 (1) : 3036.

Tarazi, Ramzi E. N. (2013). Determinants of Capital Structure: Evidence from Thailand Panel Data. Proceedings of 3rd Global Accounting, Finance and Economics Conference. No. (1958) : 1-9.

Tariq, Ali. (2015). The Joint-Determinants of Leverage and Dividend Policy: A Balanced Panel Study of Non Financial Firms of India. European Scientific Journal. Vol. 11 (10) : 311-28.

Wardhana, Guruh Hanityo. (2013). Pengaruh Profitability. Asset Tangibility dan Institutional Ownership terhadap Struktur Modal dan Dampaknya pada Kebijakan Dividen. Tesis. Universitas Diponegoro.

Wasike, Titus W. (2015). Determinants of Dividend Policy in Kenya. International Journal of Arts and Entrepreneurship. Vol. 4 (11) : 71-80. 